The Brock Review Volume 11 No. 2 (2011)

(C) Brock University

\title{
Roman Tomb Gardens: The Construction of Sacred Commemorative Landscapes
}

Nadine Brundrett

\begin{abstract}
Roman tombs were often beautified by commemorative gardens. These loci were the result of a synthesis of religious attitudes towards burials and gardens, and they signified the ancient connection between commemoration and land ownership. These gardens were often termed "farms", "orchards" or "estates" in epitaphs implying that the cultivated space was as important to the commemorators as the tombs were. The presence of these gardens around tombs offered a pleasant locale for an eternal dwelling, but more importantly they provided a productive garden to help pay for its upkeep. Roman necropoleis were not lonely places, but landscapes filled with exuberant plantings of flowers, fruit trees and vines emblematic of the ideal Roman locus amoenus.
\end{abstract}

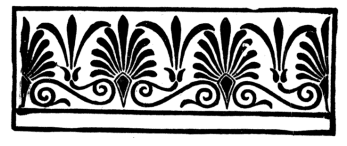

Roman identity was bound to the land, and thus the cultivation and stewardship of the land was an ancient and fundamental feature of their culture. This connection was made manifest in the ownership of productive villa estates in the countryside and domestic gardens within the urban environment; but this connection did not cease with death, as it was maintained in the commemorative realm as well. The tradition to construct monumental tombs set within plots of land resulted over time in the development of purposely designed funerary landscapes, which many Romans viewed as necessary and beneficial environments for their eternal dwellings. The construction of designed garden landscapes within the funerary realm allowed many Roman families to foster an enduring relationship with nature within the locus of their tomb, and associated with the physical tombs were the religious rites which also governed the way in which Romans understood death and the significance of the burial site. These rituals ensured that site where the remains were interred became a locus for future visitation and veneration by surviving family members. The interconnection of the physical and sacral elements within these funerary landscapes corresponded to similar cultural ideas surrounding the sacral role of natural and productive landscapes for the Romans, and it is this religious interconnection between landscape and commemoration that will form the focus of this paper. 
Ancient Roman law forbade burial within the city which meant that all burials and commemorations were located outside city limits. ${ }^{1}$ Over time this prohibition resulted in the development of necropoleis - or cities of the dead - arranged along the roadsides of busy streets outside the cities of the Roman world. Constructed tombs were the primary feature of these necropoleis, and these were erected in all manner of design: as intentionally conspicuous and grand as the builder could afford. This meant that the tombs of the wealthy were rather more ostentatious than those of the moderately rich; but regardless of size, these tombs were physical reminders of the value placed on commemoration within Roman society. The tomb design and decoration, its epitaph and its surrounding locus were all fabricated to create a carefully crafted image which provided the deceased with a measure of eternal glory and immortality. ${ }^{2}$ By the late Republic tombs had become so fashionable that they were employed by both wealthy and well-to-do Romans to ensure that their social contributions would be noted and remembered, and their placement along a busy thoroughfares ensured that even in death they remained part of the world of the living. ${ }^{3}$

During the last century of the Republic and the first century of the Empire, Romans predominantly practiced the rite of cremation. ${ }^{4}$ After a corpse was cremated in an ustrinum or bustum (a space set aside for this function outside the city limits), the bones and some ashes were gathered up and placed in a cinerary urn. The urn was then either buried in the ground beside the tomb or placed directly within the tomb itself. Once the last rites had been conducted, and the body set into its final resting place, the area of the burial was considered sacrosanct, and was termed a locus religiosus. ${ }^{5}$ Thus the land which held the burial was now a locus of veneration, and this procedure rendered the land no longer subject to human ownership, but under the protection of divine law. ${ }^{6}$ Romans distinguished between two different forms of divine law: res sacra and res religiosa. Gaius states (Inst. 2.4) that sacred (sacrae) things are those which are consecrated to the gods above, while religious (religiosae) things are those which are left to the gods below (the dii Manes). This meant that consecrated burials were under the care of religio privata (private religion) as opposed to official state sponsored observances.

Once the last rites were completed the area was given over to the dii Manes, or spirits of the underworld. ${ }^{7}$ This seems to have been the customary belief based on the vast numbers of epitaphs which began by dedicating the tomb to the individual who was now considered part of the collective spirits of the underworld. ${ }^{8}$ Once this had occurred, the land was subsequently removed from any human interference: it could not be sold, given away or otherwise violated from its original funerary 
function. Yet, Roman funerary epitaphs reveal standardized phrases cautioning against any such interference revealing that this must have been a common concern for many testators.

But beyond providing a locus for burial, Cicero hinted that the land may have contained an even deeper symbolism. Cicero stated that although Romans of his day practiced cremation, he believed that in earlier times the ancestral custom was one of internment. ${ }^{10}$ He likened this custom to a body being restored to the earth as if a mother's covering was drawn over it. ${ }^{11}$ Cicero then recounted that even a cremated body did not achieve a religious quality until some earth was thrown on it, and only then did it fall under the protection of the laws of sanctity. ${ }^{12}$

As deities, the dii Manes were viewed as powerful subjects of propitiation, and Roman religious custom bade surviving family members to visit the tombs of their relatives on the anniversaries of their deaths and during festivals of the dead in order to provide offerings. ${ }^{13}$ The main public festival for the dead, the Parentalia, was held for nine days in February, and it concluded with a public banquet on the $21^{\text {st }}$ known as the Feralia. On this day family members would banquet near the tomb and offer the dii Manes simple gifts, such as food, wine, salt, and flowers. ${ }^{14}$ This was essentially a cult of the dead, and it ensured that the deceased were provided the sustenance believed necessary for the afterlife. But above all, these rituals reinforced an ongoing connection between the departed and surviving family members ensuring that the deceased would live on in their memories.

The ancient connection between burial and ancestral estate was deeply symbolic for the Roman aristocratic elite since land ownership provided much of their wealth and social identity. For these families tombs and memorials on their estates for deceased family members helped to confirm ancestral ties to their land. ${ }^{15}$ Cicero felt that his family estate in Arpinum was beautiful and salubrious, but it was even more significant to him as his ancestral homeland since it bore the sacred traces of his ancestors. ${ }^{16} \mathrm{~A}$ similar notion confirming the significant association between land ownership and family burials was raised by elite landowners after the passing of the Agrarian law by Tiberius Gracchus in 133 BC. Affected aristocrats protested the redistribution of "public lands" which their families had gained during earlier conquests. One of the arguments cited against the reallocation of these lands to the poor was that these estates contained the graves of their forebears. What is understood here is that if they lost the rights to these lands they would not be able to care for, and appropriately honour, the burials of their relatives. ${ }^{17}$

This deeply felt sentiment between commemoration and hereditary estate was echoed in the Imperial period by Martial in a poem which praised the commemorative choices of one Roman couple following the loss of their daughter. (1.116): 
This grove (nemus) and these beautiful acres of tilled land, Faenius has consecrated to the eternal honour of her ashes. In this tomb is placed Antulla, snatched too quickly from Her family; here both Antulla's parents will blend their dust. If someone covets this small estate (agellum), He should not hope: for all time, it shall serve its masters.

The terminology here reflects the Roman ideal: a family tomb situated within a grove (nemus), beside a small estate (agellum) with beautifully productive land. The nature of the estate has been transformed through its consecration into a sacral locus for the deceased, and the notions expressed here reflect Roman attitudes towards the land as nurturing, able to provide for the family even into eternity. In a previous poem, 1.114, Martial referred to the same estate as a suburban garden (bortos) and again he confirmed the estate as consecrated (sacravit) by the burial of Antulla's ashes.

Archaeological evidence corroborates the close and ancient association of tomb and estate at Rome. A fourth century BC chamber tomb was uncovered during the construction of the viale Marco Polo in the southern section of the city. An inscribed sarcophagi discovered in the tomb named an early member of the socially prominent Cornelian family, an otherwise unknown P. Cornelius Scapula, who was pontifex maximus, as buried within. This tomb was likely constructed on an estate located just outside the Servian wall which marked the boundary between city and countryside. $^{18}$ The tomb was found in close proximity to the fragmentary remains of a building, most likely a villa rustica which was also dated to the fourth century $\mathrm{BC} .{ }^{19}$ The interrelation of the tomb, villa and estate underscores the importance for the elite to construct these elements in close proximity to provide easy access to tend the tomb, and ensure their ancestral ties to the land.

Similarly in the late second century BC an extant tomb for the consul Servius Sulpicius Galba was constructed near the Tiber south of the Emporium of Rome. It was located on an estate which was owned by the Sulpicii Galbae family well into the Imperial period. ${ }^{20}$ The tomb was situated on a road which likely formed the boundary of the family's suburban villa complex, in this instance termed a praedia. This estate also contained a warehouse (borrea) for the storage of valuable foodstuffs including olive oil for public consumption. ${ }^{21}$ The survival of this tomb in this conspicuous location even after the region was built up with other warehouses and tenement housing in the Imperial period signified the role tombs could play in confirming elite status and land ownership for generations. This tomb was a constant reminder of the deeds and accomplishments of the builder and it underscored the wealth and social relevance of this consular family for all time. 
The preference for Roman elites to display their wealth and status through architectural displays during the Republic resulted in the growing inclination to construct conspicuous tombs in prominent locations usually along roadsides. The earliest evidence of this pattern can be traced along the Via Appia after it was constructed in 312 BC. The first suburban mile of this road offered opportunities for leading Republican families, such as the Cornelii Scipiones, the Calatinii, Metellii and Servilii, to undertake competitive building displays which emphasized their military and political successes. $^{22}$ These aristocratic families erected several monumental structures, including temples, shrines and tombs, which resulted in an area of competitive display along this busy artery. ${ }^{23}$ The close association between these temples, shrines and family sepulchres suggests that the growing pattern of use of certain extramural zones as areas dedicated to religious functions both divine and commemorative began in the Republican period.

Competitive displays of the elite affected other aspects of their lives, and for many their homes, although private, were viewed as an extension of their public dignitas (rank) and auctoritas (power). As a result there was, not surprisingly, an increase in the scale and luxury of Roman villas in the late Republic commensurate with the social status of their builders. ${ }^{24}$ For some this led them to purchase and development of suburban villas on the outskirts of Rome which contained large pleasure gardens, known as horti. These horti were physical manifestations of the wealth and status of the aristocratic elite. They were elaborately designed loci dedicated to the arts of salubritas (health) and amoenitas (pleasure), and they were also potent symbols of luxuria, otium (leisure), even symbolic for some of the decay of traditional Roman values during the this period. ${ }^{25}$ But for the owners of these horti great care and attention was paid to achieving the right mood within the villa and garden spaces through the use of imported objets d'art and landscape design. Cicero implored Atticus, who was in Greece, to purchase for him sculptures which would enable him to replicate in spirit the philosophical environment of the Academy in Athens within his Tusculan villa. ${ }^{26}$ Similarly Lucullus spent vast sums on his various properties at Rome, Tusculum and in Campania which were so architecturally awe-inspiring that he earned the moniker "Xerxes in a toga". ${ }^{27}$ The great villas and pleasure gardens of the elite of Rome were comparable to Hellenistic palaces and they intentionally expressed the tastes and cultural aspirations of their owners. ${ }^{28}$

Considering the great wealth and attention lavished on these properties, it is not surprising that several owners chose their suburban horti as suitable spots for commemoration. Cicero's search for an appropriate site for a fanum (shrine) for his deceased daughter Tullia offers a famous example. After her death in February 45 BC, Cicero considered several properties in the search for the right 
location to provide a site which would be appropriate for her fanum. He had a very specific monument in mind, and he never deviated from the idea of a shrine which would signify her apotheosis to semi-divine status. At first he was determined to purchase a property which would contain a lucus (sacred grove) or a silva (woods) to provide the most appropriate setting for her shrine. ${ }^{29}$ None of his own properties were suitable since they were all either too remote to adequately celebrate her fame or were too painful for the memories they generated. A grove on an island near his native Arpinum was proposed by Atticus, but rejected by Cicero because he believed that the isolation of the area would detract from the nature of the tribute. ${ }^{30}$ Originally Cicero planned the land to contain a shrine alone, but at Atticus' suggestion, he contemplated an accompanying villa which would afford him the possibility of a dwelling where he could grow old while tending her monument. This new notion found Cicero considering and attempting to purchase a suburban villa property, and the essential requirements were now the location and the amenities of the dwelling. However, Cicero began to reconsider his plans when he realized that he would be libel for the taxation on an elaborate monumentum (tomb), and since he considered the structure a shrine (fanum), this concerned him. At this point he considered building the shrine within the precincts of one of his homes, but he was concerned that changes in ownership would affect it. He determined that the religiosity of the site would have a better chance of being respected in the future if it was situated on open land. ${ }^{31}$ Eventually the purchase of a suburban estate was abandoned, and it may well be that he returned to an earlier suggestion by Atticus to utilize his Tusculan villa for her commemoration. ${ }^{32}$

As opposed to Cicero, who was never able to realize the goal of attaining a dedicatory suburban estate, Maecenas, a close associate of Augustus, did create a remarkable property on Esquiline hill which he used for his own commemoration. ${ }^{33}$ The site of the horti Maecenatis was an especially notable one since it was constructed on land which had been earlier employed as a potter's field. Horace evocatively describes the area in Satire, 1.8 as previously strewn with whitened bones. The reclamation and transformation of this pauper cemetery into a pleasure garden was possible only because it had never been consecrated as a locus religiosus, but instead the area had remained a loca publica, a public space, available to many destitute Romans for their burials. Since this land had not been transformed into a religious space by individual funerary rites it was possible for Maecenas to purchase it and develop it to suit his own requirements. ${ }^{34}$

After its conversion, the borti Maecenatis contained several notable architectural features including a tall tower where Nero famously watched the burning of Rome in AD 64 (Suetonius, Nero, 38.2) and an extant auditorium structure which was used for recitals. But beyond these 
structures, the gardens also contained several temples or shrines. Research on the topography of the garden suggests that Maecenas worshipped Phoebus Apollo and Pallas Athena in his horti. This was echoed by the presence of a temple dedicated to Venus Erycina within the horti of Sallust, ${ }^{35}$ and the worship of Venus within Caesar's garden across the Tiber. ${ }^{36}$ The presence of temples or sacred structures within the gardens of Maecenas suggests that he had deliberately fashioned a sacro-idyllic landscape in which to live, ${ }^{37}$ and situated on the boundary of this sacrosanct garden estate were the tombs of Maecenas and his friend Horace. ${ }^{38}$

The purposeful intention of the Roman elite in fashioning their praediae or borti into sacroidyllic landscapes is an important one to consider, since it parallels the original essence of Roman religion which, as we understand it, was bound around agricultural deities and natural spirits. These spirits inhabited sacred groves and woods which facilitates an explanation for the deep connection Romans felt to nature and gardens. Two examples include the Archaic Temple of Diana on the Aventine which likely contained a grove corresponding to the similar rustic cult centre of Diana at Nemi, and the cult of the Arval Brethren for the goddess Dea Dia in the Imperial period which was situated within a sacred grove just outside Rome. ${ }^{39}$ According to Roman tradition the Golden Age of Saturn in their mythic past was an idyllic era when man was blessed by the gods, and when mankind lived an innocent and primarily pastoral existence in harmony with nature. Beliefs such as these were entwined through out Roman literature, becoming particularly fashionable in the Augustan period especially in the poetry of Vergil which served to celebrate the dawning of a new Augustan Golden Age after the crises of the civil wars. ${ }^{40}$

These ideas spilled over into the pictorial arts and a particular genre of fresco painting, often termed sacro-idyllic, was also popularized in the late Republic. In this genre we find visions of rustic utopias perceived with great nostalgia, and sacred groves populated by trees, dwellings and shrines, all with shepherds or simple rural dwellers to tend them. This has been taken as emblematic of the reverence Romans felt for their ancestral customs, and their pietas for the gods situated within their natural environs. These paintings reveal the idealized interconnection between rural shrines and nature which were appropriate homes for spirits, and as loci amoeni they were spaces where the human and the divine worlds could intersect. ${ }^{41}$ They reflected an ideal image of the rus (countryside) and although they were not exactly reflective of urban garden landscapes, the rus in urbe as coined by Martial, ${ }^{42}$ they both shared a carefully crafted expression of sacral loci. Gardens were conceived as religious spaces which made commemoration within them all the more appropriate. ${ }^{43}$ 
But by the late Republic elite rivalry signalled the collapse of the collegial political system which has sustained Rome for so long. As individuals from leading families manoeuvred to gain political power, they pursued ways to promote themselves and their families over other potentates. Blatantly self-promoting tombs were part of the visual pageantry employed by these elite contenders in order to assert their status and position in society. ${ }^{44}$ Tombs such as the pyramid of Cestius, the tomb of Caecilia Metella, and of course the Mausoleum of Augustus, are surviving examples of this competition. ${ }^{45}$ The Mausoleum of Augustus, designed when he still bore the name Octavian, was one of the largest tomb complexes ever constructed in Rome. It was situated in the Northern Campus Martius since this area could provide ample space for the parkland which was designed to surround the sepulcher. Descriptions of the mausoleum by Suetonius and Strabo paid special attention to the grounds of the tomb. They were described as "adjacent woods and walks" by Suetonius (Aug.100.4); and Strabo likewise stated (5.3.8): "behind was a great sacred grove with wonderful promenades." The fact that the park was opened to the public in $28 \mathrm{BC}$, perhaps even before the mausoleum was completed, and that it was accompanied by wooded parkland and public walking paths, was significant enough for both writers to comment upon. It seems that in planning his honorific tomb monument Octavian had adapted earlier usages of sacral landscapes within Rome, combining elements of both the aristocratic horti and the sacred groves of the gods to suit his own needs. While the main feature of horti had always been the domestic villa, the landscaped gardens played a significant role in complementing the dwelling and establishing a mood for owner. Although Octavian's mausoleum was situated within a large landscaped park, similar to other horti, it could not qualify as a traditional estate, since there was no accompanying villa to act as a residence. Instead the tomb itself was the central element, envisioned as a triumphal-dynastic monument to display his personal consequence. But the terminology employed by Strabo suggested that this landscaped parkland, which also seemed to imitate the sacred groves previously associated with deities in Rome, was an appropriate place to house the grandiose tomb of Octavian, perhaps because he himself was also the son of a god. ${ }^{47}$

Although the design of the parkland and gardens around the Mausoleum of Augustus remains unknown, other public gardens, such as the Porticus of Pompey, the later Forum of Peace and the Temple of the Deified Claudius, contained formalized planting schemes with trees and plants in strict rows. ${ }^{48}$ Whether a similarly structured space should be reconstructed here remains conjecture. And although we do not know the species of trees or shrubs used within his commemorative grove, perhaps oaks, laurels, myrtles, palms and cypresses were utilized for their 
sacral associations as they were at other locales in Rome in order to promote the idea of the dawning of the new Golden Age brought about not by Saturn but by Octavian/Augustus. ${ }^{49}$

In general, borti were components of suburban villas and as such they were considered private spaces. They were only accessible to the people for special occasions when the owners sought to curry public favour as earlier examples set by Pompey and Caesar had demonstrated..$^{50}$ By making his funerary garden public Octavian had offered a very different message: his commemorative space with its generous parkland was to be accessible rather than exclusionary. This made the space unique; and this act of public benefaction must have increased his popularity with the people, even as the ostentatious scale of the tomb itself symbolized the reality of his political authority. The Mausoleum of Augustus with its great sacred grove became the ultimate example of the synthesis of a tomb and its locus, both constructed and shaped for their cultural expressions which served to magnify the consequence of the builder.

This trend to construct funerary landscapes which resonated with religious and commemorative symbolism was maintained into the Imperial period as the hereditary estate of the Annii attests. The property was situated between the second and third miles along the Via Appia, and in the mid second century the praedia had belonged to Annia Regilla. It passed to her husband Herodes Atticus after her sudden and mysterious death in AD $160 .{ }^{51}$ Herodes used this opportunity to extensively rebuild the older villa on the estate, creating a grand complex of buildings to compliment the central feature which was a cenotaph temple-tomb for Regilla. ${ }^{52}$ After her death Herodes had Regilla elevated to semi-divine status and at her estate he arranged that her cult would be tended by the women of Rome. ${ }^{53}$ Funerary iconography found in her tomb indicates that within her cult she was closely associated with the goddess Demeter/Ceres and the deified Empress Faustina, in whose cult she had officiated after Faustina's deification. ${ }^{54}$ On one of the epitaphs composed for Regilla, Herodes referred to the tomb as a shrine and he termed the property a Triopeion, a name which recalled the sacred precinct of Demeter on Knidos. In addition, the estate was described as sacred, burgeoning with fruitful fields of cultivated vines rich in grapes. It was also filled with acres of olive trees, crops of grains and soft meadows: "for you Herodes sanctified the land and built a rounded wall encircling it not to be moved or violated, for the benefit of future generations." 55 Indeed, this was a productive estate, and the crops harvested here now nourished the cult of Regilla and the other shrines established on this newly consecrated land. ${ }^{56}$ After the death of Herodes, in the late second century AD, the property was absorbed into the Imperial patrimony and in the early fourth century the Emperor Maxentius once again refurbished the villa complex by 
adding his own conspicuous dynastic mausoleum on via Appia to honour his deified son Romulus who died in AD 309. Although the cult was new, it was a familiar use for this land.

But not all Romans could afford to commemorate themselves within vast estates or lavish horti. For the modestly wealthy, who could not own suburban horti, the choice for appropriate commemoration was a small plot of land situated along a road-side purchased specifically for this function. But how were these modest plots envisioned by their designers? When the fictional Trimalchio, in Petronius' Satyricon, asks his tomb maker, a fellow diner, to design his plot, he states: "I want the tomb to have a frontage of 100 feet and to be 200 feet in depth, around it I want an orchard with every variety of fruit tree, and you better throw in a vineyard. It is wrong, I think, for a man to concern himself only with the house where he lives his life, and give no thought to the home he'll have forever." ${ }^{57}$ Trimalchio's concern to provide a funerary garden around his tomb is a commonly cited example for the importance of funerary gardens within the commemorative sphere, but beyond the general notion of a planted space what is striking is his stress on the creation of a productive garden. This idea is echoed in numerous epitaphs across the Roman world. Funerary terminology allows us to reconstruct the desire of many tomb builders to establish a productive garden or agricultural space within their funerary plot. Terms such as hortus (garden), praedium (estate), fundus (farm), ager (field), pomarium (orchard), and vinea (vineyard) offer some examples of this aspiration. ${ }^{58}$ Some epitaphs offer even more details. For example, the epitaph of two quaestors from the Cocceii family discovered on the Via Labicana outside Rome indicates that these men arranged their tomb to be "adorned with the vines, fruit-trees, flowers, and the seeds of all kinds of plants." 59 Another man asks that his heir "makes his mausoleum fruitful by planting trees, vines and roses." This latter inscription was found at Nimes, in Southern France, revealing the wide-spread appeal of these sentiments.

But whom was this produce for? Trimalchio stated that he wanted one of his freedmen to act as a steward of his tomb to "prevent people from running up and crapping on it." "This was a very real threat which must have encouraged many tomb builders to protect their sepulchres from similar abuses through the utilization of a custodian. ${ }^{62}$ In these instances we should expect that garden produce from these plots would generate some income which could help support the cost of the custodian. And as N. Purcell noted although satirical literary descriptions of Rome's suburban region frequently depict it almost as a useless area filled with artificial pleasure villas, in fact food production remained the economic mainstay of this area. The suburbium functioned as the market garden of Rome, making even relatively modest plots of land significant in this equation. ${ }^{63}$ 
In addition to selling produce, funerary gardens could be harvested and utilized by family members for their own enjoyment and even be shared with the dii Manes during funerary banquets. The above mentioned tomb of the Cocceii also included elaborate dining facilities with "a square table in the summer house, an ornamental slab-topped table with a pedestal, a sundial, a basin with marble supports and a well." ${ }^{, 64}$ Clearly for these men the continued opportunity for elegant dining at their sepulchre, perhaps as much for their infernal shades as for their heirs, was a significant consideration in planning a verdant and productive plot.

For another couple who planned a modest monument with a garden, it was a sacred nature of the space which appealed to their sentiments: “...this place, with its sacred little garden and its little building, encircled by a wall, belongs to the tomb of Mindia Iulia and P(ublius) Aelius Philetus..." ${ }^{65}$ They refer to their plot as hortulus religiosus emphasizing the religious nature of even this modest space which enveloped their eternal dwelling. The mention of encircling walls (maceria) was a common feature on numerous epitaphs which mirrors the use of walls, fences or cippi (markers) to demarcate the physical boundaries of these spaces. Similarly domestic gardens also used boundary markers or walls to control access within the space and to ensure that they remained private and inviolate. ${ }^{66}$

To indicate the size of the funerary gardens many commemorators, just as Trimalchio, dictated the dimensions of their plot. The sheer quantity of surviving epitaphs from Rome and the empire with the formulaic phrase, in fronte pedes... (across the front so many feet...), in agro pedes... (into the field so many feet...), indicates that the mention of the exact dimensions of the plot were popular to include. Part of the concern to list the size of the plot was surely a legal one, to ensure that others knew its dimensions and thus the sacrosanct land which was set aside for the burial would not be violated, especially by later burials. ${ }^{67}$ Another reason for the prevalence must surely be pride of ownership especially for the modestly wealthy, who could not afford vast estates for commemoration, but instead who took great satisfaction in the achievement of their more modest commemorative dreams. This was especially true for former slaves who could use these monuments to declare their citizenship and subsequent social worth. And although the commemoration of these modestly wealthy Romans could never be on the same scale as the elite, their epitaphs do not reveal any differences in the terminology employed to describe their funerary landscapes. Consider another epitaph of a couple from Rome:

Gaius Hostius Pamphilus, a freedman, and a doctor, this monument bought, for himself and for Nelpia Hymnina, a freedwoman, and for all their freedmen and 
freedwomen, and their descendants. This is our eternal house (domus aeterna), this is our farm (fundus), these are our gardens (horti), this is our tomb (monumentum). Across the front 13 feet, into the field 23 feet. $^{68}$

The desire of the couple for an eternal house, a farm and a substantial garden are wonderful sentiments, but the reality of the size of the plot given as $13 \times 23$ feet, meant that all of these features had to be contained within a modest area. Even assuming a tomb of diminutive size, there could not have been room for a generous garden space within this monument. Moreover, the use of elite commemorative terminology and practices by more modestly wealthy Romans reveals that these were either abstract ideals or fashionable sentiments chosen to reflect general commemorative desires rather than attainable goals for these individuals. Cost was an unfortunate reality for many, and the suburbium of Rome contained some of the most expensive land in the Empire. ${ }^{69}$

We have no way of knowing the general preference for productive gardens versus purely pleasurable ones within the commemorative sphere, but we can perhaps determine additional inspirations for productive landscapes beyond the purely practical considerations. Bearing in mind that many family estates bore a long standing correlation between production and commemoration, it is not too extreme to suggest one of the inspirations for the use of productive gardens within tombs may have extended from this ancient tradition. Although other sources have been sought within the Greek world, especially within the garden tombs of the necropoleis of Alexandria, we do not need to search so far a field. ${ }^{70}$ Rather the prevalent use of the term cepotaphion (tomb garden) within both Greek and Roman epitaphs speaks to the commonly shared idea of the desirability of these cultivated and sustaining landscapes across the Greco-Roman world.

In the end we must ask what kind of dialogue these gardens established with the viewer. Trees and shrubs rising above the walls of these gardens would have offered a visually attractive backdrop to the hustle and bustle of the traffic along the street, but aside from notable exceptions such as the Mausoleum of Augustus, we must remember that these plots were essentially private spaces, and their very association with private familial rites rendered them exclusive. These cultivated spaces were certainly significant for the tomb builders, as the epigraphical testimony reveals. Their inclusion within the funerary landscape was a reflection of general attitudes towards the land and commemoration, and we can appreciate this significance for the Romans. Perhaps for some the garden was simply a lovely feature to add to their eternal home, or a desirable space to produce a small additional income for the upkeep of the monument, but for others the garden may have played 
a deeper role, fulfilling a need to express their piety and reverence to their religious beliefs and ancestral traditions.

Today, when we visit an ancient necropolis we need to reconstruct a different picture in our minds than the one frequently presented to us. Rather than a lonely place filled with simple grasses or weeds, and a perhaps a few trees as representative of the ancient splendor, we must recreate a landscape which was filled with exuberant plantings of flowers, fruit trees, vines, with their accompanying buildings all emblematic of the ideal Roman locus amoenus.

Martial sums it up best in an evocative poem which reflects these universal attitudes towards sacred landscapes which could continue to nurture the deceased forever. (1.88):

Alcimus, whom was snatched from his master in his growing years,

Let Lavican soil cover with light grass,

Take not a Parian marble monument of staggering weight,

The perishable gift which vain toil turns to dust,

But malleable boxwood and the vine's dense shadow

And a meadow that grows green, dewy with my tears,

Take them, beloved boy, as tokens of my sorrow,

Here for all time shall your honour live,

And when the fates have spun to the end my last years,

My ashes shall lie in no other place.

\section{Notes}

${ }^{1}$ Cicero relates, de Leg. 2.23.58, that this was a legal requirement dating back to the time of the Twelve Tables.

${ }^{2}$ Varro, Ling Lat, 49, uses the term monument to imply an epitaph which is placed on the tomb situated along the road. The epitaph is intended to admonish the passers-by that they too were mortal. Varro goes on to state that it was the things that are written and done in order to preserve memory that are called monuments. See also M. Koortbojian, "In commemorationem mortuorum: text and image along the 'streets of tombs", in J. Elsner (ed) Art and Text in Roman Culture, Cambridge, 1996, 210-233.

${ }^{3}$ For general discussions on the role of commemoration in the Roman world see: J.M.C. Toynbee, Death and Burial in the Roman World, Baltimore and London, 1971; H. von Hesberg, Monumenta: I sepolcri Romani e la loro architettura, Milan, 1994; M. Carroll, Spirits of the Dead: Roman Funerary Commemoration in Western Europe, Oxford, 2006; V.M. Hope, Death in Ancient Rome: A Sourcebook, London and New York, 2007.

${ }^{4}$ This practice was so prevalent that Tacitus, Ann. 16.6, referred to it as Romanus mos (the Roman custom).

${ }^{5}$ According to Cicero, de Leg. 2.21.55-57, the customary last rites included the sacrifice of a sow for the deceased who was nourished by the smell of the animal. After eight days another animal was sacrificed in the home to the lares and this was consumed by the family. After this ritual banquet the 
family was released from their death pollution. See also "Dead, cult of the" in Brill's New Pauly: Encyclopedia of the Ancient World, Leiden, 2002-2010.

${ }^{6}$ Gaius, Inst. 2.6-9. A Roman citizen could designate a funeral plot on his own land; this was done by permitting the burial and the associated rites. It was felt that the head alone was necessary for the burial to be sacred (Digest, xi.7.44), but cenotaphs could also be designated religiosus through the employment of the appropriate rites (Digest, i.8.6). G.A. Harrer, "A meaning of Religiosus", Classical Philology 19 (1924) 83-4.

${ }^{7}$ Cicero, Tusc. 1.8, 1.12. It should be noted, however, that there were numerous beliefs surrounding life after death and the survival of the soul, and that some branches of Greek philosophy did produce skeptics, but these ideas likely circulated primarily amongst the elite and did not generally affect the majority of the population. The very ubiquity of tombs dedicated to the infernal shades indicates the need felt by most Romans to provide an eternal resting place for themselves or their family members.

${ }^{8}$ The di Manes, or infernal shades, were considered to be the 'souls' or 'spirits' of properly buried individuals. They seem to have been only vaguely conceived in Roman religion, but were significant as minor deities who required propitiation and reverence by surviving family members and their descendants. They seem to have required a tomb, or proper burial plot as a dwelling, to prevent them from returning and interfering with their original home. See "Manes, di" in Brill's New Pauly: Encyclopedia of the Ancient World, Leiden, 2002-2010.

${ }^{9}$ The reality was that burial space was expensive and valuable. Tombs regularly suffered abuse as they were reused, altered and destroyed over time.

${ }^{10}$ Cicero states, de Leg. 2.22.55, that it was customary to remove a finger prior to cremation for a separate burial in the earth to symbolize this earlier ritual.

${ }^{11}$ Cicero, de Leg. 2.22.56, states that "the body is restored to earth, and placed and laid to rest as if its mother's covering were drawn over it."

${ }^{12}$ Cicero, de Leg. 2.22.57. The passage has been corrupted, but this seems to be the sense of his discussion.

${ }^{13}$ Vergil, Aeneid 5.46ff; Ovid, Fasti 2.533ff. J. Bodel notes that this custom was a fundamental feature of Roman religion which is why it became an element within the official religious calendar. J. Bodel, "Monumental villas and villa monuments" JRA 10 (1997) 5-35 at 21.

${ }^{14}$ Varro, Ling Lat. 6.13.

${ }^{15}$ J. Bodel, "Monumental villas and villa monuments" JRA 10 (1997) 5-35.

${ }^{16}$ Cicero, de Leg. 2.3.

${ }^{17}$ Appian, Bell Civ. 1.10.

${ }^{18}$ The tomb and associated structures were found some $400 \mathrm{~m}$ to the west of the Via Appia. The estate most likely predates the development of the Via Appia under Appius Claudius Caecus in 312 BC.

${ }^{19}$ G. Pisani Sartorio and S. Quilici Gigli, “A proposito della Tomba di Corneli” BullCom 1987/1888, 247-264. See also discussions in J.R. Patterson, "On the margins of the city of Rome" in V. M. Hope and E. Marshall (eds) Death and Disease in the Ancient City, London and New York, 2000, 85-103. ${ }^{20}$ The inscription on the tomb reads: Ser. Sulpicius Ser.f. / Galba cos. / ped. quadr. XXX. (CIL VI $31617=I L S$ 863). "Servius Sulpicius, son of Servius, Galba, consul, (this plot is) thirty feet square." There are two known consuls of this name: a father and son. The father was consul in $144 \mathrm{BC}$ and the son in 108 BC. Scholars are not sure which man is named in the epitaph, but opinion favours the son. L. Richardson jr., A New Topographical Dictionary of Ancient Rome, Baltimore and London, 1992, 
356; B. Frischer, "Monumenta et Arae Honoris Virtutisque Causa: Evidence of Memorials for Roman Civic Heroes" BullCom 88 (1982-3) 51-86.

${ }^{21}$ On the Severan Marble Plan the property was termed: [PRAED]IA ET HORREA [G]ALB[ANA] "The estate and warehouse of the Galbae." L. Haselberger, et.al., Mapping Augustan Rome, JRA supp. 50, Portsmouth, RI, 2002, 140. See also "Horrea Galbae" in M. Steinby (ed), Lexicon Topographicum Urbis Romae, Rome, 1993-2000.

${ }^{22}$ Cicero, Tusc. 1.7.13.

${ }^{23}$ The Via Appia quickly became a heavily traveled artery linking Rome to many hinterland communities to the south. See discussion in N. Purcell, "Tomb and Suburb" in H. von Hesberg and P. Zanker (eds) Römische Gräberstraßen Selbstdarsteilung - Status - Standard, Munich, 1987, 25-41 at 28; J.R Patterson, "On the Margins of the City of Rome" in V. Hope and E. Marshall, eds. Death and Disease in the Ancient City, London and New York, 2000, 85-103.

${ }^{24}$ T.P. Wiseman, "Conspicui postes tectaque digna deo: The public image of aristocratic and imperial houses in the Late Republic and Early Empire", in L'Urbs: Espace urbain et histoire, Rome, 1987, 393413. See also A. Wallace-Hadrill, Houses and Society in Pompeii and Herculaneum, Princeton, 1994.

${ }^{25}$ K. T. von Stackelberg, The Roman Garden: space, sense and society, London and New York, 2009, 12 and 74 .

${ }^{26}$ These letters are collected and discussed in M. Marvin, "Copying in Roman Sculpture: The Replica Series" in E. D'Ambra (ed) Roman Art in Context: An Anthology, Eaglewood Cliffs, New Jersey, 1993, 161-188 at 162-7.

${ }^{27}$ Plutarch, Lucullus, 37, 39.

${ }^{28}$ A.L. Giesecke, The Epic City: Urbanism, Utopia and the Garden in Ancient Greece and Rome, Cambridge, Massachusetts, 2007, 104-9.

${ }^{29}$ See terminology in the letters 329 (xiii.22).4 and 272 (xii. 31).2 as collected and edited in D.R. Shackleton Bailey Cicero's Letters to Atticus, vol. 5, Cambridge, 1966.

${ }^{30}$ See letters: 259 (xii.12). 1 and 329 (xii.22).4.

${ }^{31}$ Letter: 275 (xii.36).1.

${ }^{32}$ Letter: 276 (xii.37).2. See the extensive discussion in D.R. Shackleton Bailey, Cicero's Letters to Atticus, Cambridge, 1966, vol. 5, 404-413.

${ }^{33}$ The horti Maecenatis was likely constructed during the competitive decade of the 30's BC. K.T. von Stackelberg, The Roman Garden: space, sense and society, London and New York, 2009, 78.

${ }^{34}$ Cicero relates, de Leg. 2.58, that loca publica could not be encumbered by private religious observances which would render them religio privata and thus the land sacrosanct and inviolate. See discussion in J. Bodel, "Dealing with the dead: Undertakers, executioners and potter's fields in ancient Rome" in V. Hope and E. Marshall (eds) Death and Disease in the Ancient City, London and New York, 2000, 128-151 at 134.

${ }^{35}$ C. Häuber, "The Esquiline Horti: New Research" in A. Frazer (ed) The Roman Villa: Villa Urbana, Philadelphia, 1998, 55-64 at 59.

${ }^{36}$ Venus was an obvious choice to worship in a garden since she was known as a goddess of gardens. This is readily confirmed by the number of references to Venus within the gardens of Pompeii. K.T. von Stackelberg, The Roman Garden: Space, sense and society, London and New York, 2009, 87-89. ${ }^{37}$ The Diaeta Apollonis no longer survives but was a structure in this garden which was somehow associated with Apollo. C. Hüber suggests that it may have resembled the Museion in Alexandria which was part of the palace complex of the Ptolemaic dynasty. C. Häuber, "The Esquiline Horti: New Research" in A. Frazer (ed) The Roman Villa: Villa Urbana, Philadelphia, 1998, 55-64 at 59, 64. 
${ }^{38}$ Suetonius records, vita Hor. 20, that the tomb of Horace was extremis Esquiliis, iuxta Maecenatis tumulum. "... on the far Esquiline, next to the Tumulus of Maecenas." The structure known as the "Casa Tonda," extant until 1886 on the Via Labicana in this area, was a tumulus tomb designed with a large drum on a square base; the drum measured 20 meters in diameter. This tomb has been tentatively identified as the mausoleum of Maecenas. See "Sepulcrum: Maecenas" in M. Steinby (ed), Lexicon Topographicum Urbis Romae, Rome, 1993-2000.

${ }^{39}$ M. Beard, J. North, S. Price, Religions of Rome, vol.2, Cambridge, 1998, 87-8.

${ }^{40}$ The poetry of Vergil in particular celebrates the ideals of both the new Augustan utopia and the restoration of traditional values through his evocative descriptions of sacral and pastoral landscapes. A.L. Giesecke, The Epic City: Urbanism, Utopia, and the Garden in Ancient Greece and Rome, Cambridge, Massachusetts and London, 2007, 126-8.

${ }^{41}$ A.L. Giesecke, The Epic City: Urbanism, Utopia, and the Garden in Ancient Greece and Rome, Cambridge, Massachusetts and London, 2007, 122-5.

${ }^{42}$ Martial, Epigrams, XII.57.21.

${ }^{43}$ See further discussion in P. Grimal, Les Jardins Romains, $3^{\text {rd }}$ ed, Paris, 1984, 303-337.

${ }^{44}$ W. Eck, "Senatorial self-representation: development in the Augustan period", in Caesar Augustus: Seven Aspects, eds. F. Millar and E. Segal, Oxford, 1984, 129-167 at 129-30.

${ }^{45}$ P. Zanker notes that ironically neither G. Cestius nor Caecilia Metella had access to any real power, so the tombs did little but display the great wealth of the families. P. Zanker, The Power of Images in the Age of Augustus, translated, A. Shapiro, Ann Arbor, 1988, 15-16.

${ }^{46}$ Strabo employs the Greek term "alsos" which can mean "grove" or "sacred grove".

${ }^{47}$ After the deification of Julius Caesar, his heir Octavian was able to refer to himself as the son of the deified Caesar (Caesar Divi filius). This terminology appeared regularly on his coinage and on his honorific inscriptions.

${ }^{48}$ A.L. Kuttner, "Culture and History at Pompey's Museum” TAPA 129 (1999) 343-373; R.B. Lloyd, “Three monumental gardens on the Marble Plan” AJA 86 (1982) 91-100.

${ }^{49}$ For more discussion on this see B.A. Kellum, "The Construction of Landscape in Augustan Rome: The Garden Room at the Villa ad Gallinas" The Art Bulletin 76.2 (1994) 211-224.

${ }^{50}$ J. H. D'Arms, "Between public and private: the epulum publicum and Caesar's horti trans Tiberim" in M. Cima and E. La Rocca (eds) Horti Romani, Rome, 1998, 33-43.

${ }^{51}$ Regilla died when she was eight months pregnant with the couple's fifth child. Her husband was accused of kicking her in the stomach and he was brought to trial in Rome by Regilla's brother.

Although he was exonerated he spent the rest of his life constructing many elaborate monuments in her memory. Most were in Greece, his own homeland, but outside Rome he did refurbish her ancestral property into a shrine for her. See discussions in S.B. Pomeroy, The Murder of Regilla: a Case of Domestic Violence in Antiquity, Cambridge, Massachusetts, 2007.

${ }^{52}$ While the final resting place of Regilla is not known, it is generally held to have been in Athens where Atticus had erected another temple tomb to her in the suburb of Marousi. S.B. Pomeroy, The Murder of Regilla: a Case of Domestic Violence in Antiquity, Cambridge, Massachusetts, 2007, 137.

${ }^{53}$ Six Greek inscriptions in all were discovered on the property. The longest was a eulogy poem commissioned by Herodes to honour Regilla. As a non-Imperial mortal she could not be truly deified, but she could be heroized. And thus one of the epitaphs states she had neither a sacred temple nor a tomb, but a shrine. See the English translations in S.B. Pomeroy, The Murder of Regilla: a Case of Domestic Violence in Antiquity, Cambridge, Massachusetts, 2007, 170-4. 
${ }^{54}$ Her tomb was situated in the heart of the estate rather than right on the Via Appia as was typical; it was later transformed into the church of Sant'Urbano. K. Noreen, 'Sant'Urbano alla Caffarella, Rome: the Reconstruction of an Ancient Memorial” MAAR 47 (2002) 57-82.

${ }^{55}$ As translated by S. Pomeroy, The Murder of Regilla: a Case of Domestic Violence in Antiquity, Cambridge, Massachusetts, 2007, 170-4.

${ }^{56}$ Evidence on the property suggests that several other cults were also worshipped here including: Ceres, Proserpina, Minerva, Nemesis, Isis, Serapis, Bacchus Sabazius and Diana. See K. Noreen, "Sant'Urbano alla Caffarella, Rome: the Reconstruction of an Ancient Memorial" MAAR 47 (2002) $57-82$ at 71.

${ }^{57}$ Petronius, Satyricon, 71.

${ }^{58}$ J.M.C. Toynbee, Death and Burial in the Roman World, Baltimore and London, 1971, 94-7.

${ }^{59}$ CIL, VI, 10237; ILS, 7870: “...vitium pomorumque et florum viridumque omnium generum seminibus ea loca...adornaverunt..."

${ }^{60}$ CIL, XII, 3637: "mausoleum excoluit et ut esset fru [giferum feci] tpositis arboribus vitibus rosariis."

${ }^{61}$ Petronius, Satyricon, 71.

${ }^{62}$ In the city of Rome a common epigraphical phrase was: buic monumento dolus malus abesto (let this monument be free from intentional desecration) revealing that abuse and especially reuse of these structures was real concern for testators. M. Carroll, Spirits of the Dead: Roman Funerary Commemoration in Western Europe, Oxford, 2006, 79-85.

${ }^{63}$ N. Purcell, "The Roman villa and the landscape of production" in T. Cornell and K. Lomas (eds.) Urban Society in Roman Italy, New York, 1995, 151-179.

${ }^{64}$ CIL, VI, 10237; ILS, 7870: “...mensam quadratam in trichila, abacum cum basi, horologium, labrum cum fulmentis marmoreis, putiale, posuerunt..."

${ }^{65}$ CIL, VI, 22518: “... Hic locus, cum hortulo suo religioso et aedificiolis suis, muro cinctus, ad sepulcrum Mindiae Iuliae et P. Aeli Phileti pertenet (!)...”

${ }^{66}$ For a discussion on significance of the boundaries of domestic gardens see: K.T. von Stackelberg, The Roman Garden: space, sense and society, London and New York, 2009, 54-5.

${ }^{67}$ Cicero, de Leg. 2.55.

${ }^{68}$ CIL, VI, 9583 = ILS 8341: C. Hostius C.l. Pamphilus / medicus hoc monumentum / emit sibi et Nelpiae M.l. Hymnini / et liberteis et libertabus omnibus / postereisque eorum. / Haec est domus aeterna, bic est / fundus, heis sunt horti, hoc / est monumentum nostrum / in fronte p(edes) XIII, in agrum p(edes) XXIII.

${ }^{69}$ E. Champlin, "The Suburbium of Rome" AJAH 7.2 (1982) 97-117 at 102.

${ }^{70} \mathrm{~N}$. Purcell suggests that the inspiration for funerary gardens may have derived in part from Hellenistic Alexandria with its sprawling suburbs of cemeteries and gardens. He cites Strabo, 17.1.10, which refers to one suburb specifically as the Necropolis "in which there are many gardens and tombs and installations suitable for the mummification of corpses." Yet this image this does not differ greatly from the reconstructed impression of the Via Appia during the Republican period with its temples, tombs and villa gardens. See N. Purcell, "Tomb and Suburb" in H. von Hesberg and P. Zanker (eds) Römische Gräberstraßen: Selbstdarsteilung - Status - Standard, Munich, 1987, 25-41 at 29-30. 


\section{Bibliography}

Beard, M., J. North and S. Price. Religions of Rome. Vol.2. Cambridge: Cambridge University Press, 1998.

Bodel, J. "Monumental villas and villa monuments." Journal of Roman Archaeology 10 (1997): 5-35.

---. "Dealing with the dead: Undertakers, executioners and potter's fields in ancient Rome." In Death and Disease in the Ancient City, edited by V. Hope and E. Marshall, 128-151. London and New York: Routledge, 2000.

Carroll, M. Spirits of the Dead: Roman Funerary Commemoration in Western Europe. Oxford: Oxford University Press, 2006.

Champlin, E. “The Suburbium of Rome." American Journal of Ancient History 7 no. 2 (1982): 97-117.

D'Arms, J.H. "Between public and private: the epulum publicum and Caesar's horti trans Tiberim." In Horti Romani, edited by M. Cima and E. La Rocca, 33-43. Rome: "L'Erma" di Bretschneider, 1998.

Eck, W. "Senatorial self-representation: development in the Augustan period." In Caesar Augustus: Seven Aspects, edited by F. Millar and E. Segal, 129-167. Oxford: Clarendon Press, 1984.

Frischer, B. "Monumenta et Arae Honoris Virtutisque Causa: Evidence of Memorials for Roman Civic Heroes.” Bullettino della commissione archeologica communale di Roma 88 (1982-83): 51-86.

Giesecke, A.L. The Epic City: Urbanism, Utopia and the Garden in Ancient Greece and Rome. Cambridge: Harvard University Press, 2007.

Grimal, P. Les Jardins Romains, $3^{\text {rd }}$ ed. Paris: Fayard, 1984.

Harrer, G.A. “A meaning of Religiosus.” Classical Philology 19 (1924): 83-4.

Hope, V.M. Death in Ancient Rome: A Sourcebook. London and New York: Routledge, 2007.

Haselberger, L. et.al. Mapping Augustan Rome. Journal Roman Archaeology supp. 50. Portsmouth, RI, 2002.

Häuber, C. "The Esquiline Horti: New Research.” In The Roman Villa: Villa Urbana, edited by A. Frazer, 55-64. Philadelphia: University Museum, University of Pennsylvania, 1998.

Kellum, B.A. "The Construction of Landscape in Augustan Rome: The Garden Room at the Villa ad Gallinas." The Art Bulletin 76 no. 2 (1994): 211-224.

Koortbojian, M. "In commemorationem mortuorum: text and image along the 'streets of tombs." In Art and Text in Roman Culture, edited by J. Elsner, 210-233. Cambridge, Cambridge University Press, 1996.

Kuttner, A.L. "Culture and History at Pompey's Museum." Transactions of the American Philological Association 129 (1999): 343-373.

Lloyd, R.B. "Three monumental gardens on the Marble Plan." American Journal of Archaeology 86 (1982): 91-100.

Marvin, M. "Copying in Roman Sculpture: The Replica Series." In Roman Art in Context: An Anthology, edited by E. D’Ambra, 161-188. Eaglewood Cliffs, NJ: Prentice Hall, 1993.

Noreen, K. "Sant'Urbano alla Caffarella, Rome: the Reconstruction of an Ancient Memorial." Memoirs of the American Academy in Rome 47 (2002): 57-82.

Patterson, J.R. "On the margins of the city of Rome." In Death and Disease in the Ancient City, edited by V. M. Hope and E. Marshall, 85-103. London and New York: Routledge, 2000.

Pisani Sartorio G. and S. Quilici Gigli. "A proposito della Tomba di Corneli." Bullettino della commissione archeologica communale di Roma (1987/88): 247-264. 
Pomeroy, S.B. The Murder of Regilla: a Case of Domestic Violence in Antiquity. Cambridge: Harvard University Press, 2007.

Purcell, N. "Tomb and Suburb." In Römische Gräberstraßen Selbstdarsteilung - Status - Standard, edited by H. von Hesberg and P. Zanker, 25-41. Munich, 1987.

---. "The Roman villa and the landscape of production." In Urban Society in Roman Italy, edited by T. Cornell and K. Lomas, 151-179. New York: St. Martin's Press, 1995.

Richardson, L. Jr. A New Topographical Dictionary of Ancient Rome. Baltimore and London: Johns Hopkins University Press, 1992.

Shackleton Bailey, D.R. Cicero's Letters to Atticus, Vol. 5. Cambridge, 1966.

Steinby, M., ed. Lexicon Topographicum Urbis Romae. Rome: Edizioni Quasar, 1993-2000.

Toynbee, J.M.C. Death and Burial in the Roman World. Baltimore and London: Johns Hopkins University Press, 1971.

von Hesberg, H. Monumenta: I sepolcri Romani e la loro architettura. Milan: Longanesi, 1994.

von Stackelberg, K.T. The Roman Garden: space, sense and society. London and New York: Routledge, 2009.

Wallace-Hadrill, A. Houses and Society in Pompeii and Herculaneum. Princeton: Princeton University Press, 1994.

Wiseman, T.P. "Conspicui postes tectaque digna deo: The public image of aristocratic and imperial houses in the Late Republic and Early Empire." In L'Urbs: Espace urbain et histoire, 393-413. Rome, 1987.

Zanker, P. The Power of Images in the Age of Augustus. Translated by A. Shapiro. Ann Arbor: University of Michigan Press, 1988. 